\title{
An electrophoratic study of protein patterns in the fat bodyand haemolymphof the solitary form of the desert locust Schistocercagregaria(Foraskal).
}

\author{
Aly, G.M. ${ }^{\mathrm{a}}$, Emtithal. M. Abd-Elsamie ${ }^{\mathrm{b}}$ \\ ${ }^{a}$ Natural products Department,National Center for Radiation Research and Technology (NCRRT), Egyptian \\ Atomic Energy Authority \\ ${ }^{b}$ Department of Entomology, Faculty of Science, Cairo University
}

\begin{abstract}
The polyacrylamide gel electrophorasis (PAGE) was performed on the fat bodyand haemolymphof the $5^{\text {th }}$ nymph instar as well as three different phases of adult males and females namely; newly emerged, yellow and non yellow males (mature and non-matur), before and after oviposition females of the desert locust Schistocercagregaria. The total number of protein bands detected in the fat body and haemolymphwere 44,37respectively. The concentrationpercentage of these protein bands, the timing of band appearance and disappearance, the sex-specific proteins and the major protein bands forthe fat body and haemolymphwere detected. The protein metabolism was studied and discussed by observing and comparing the different protein patterns of the fat body tissues and the haemolymph fluid of the desert locust.
\end{abstract}

Key words: Schistocercagregaria, Electrophoretic study, Fat body, Haemolymph,Solitary form.

\section{Introduction}

Locust swarms cause great damage to grassland, agriculture crops and various other plants. This damage in the invasion territories of the desert locust, Sch. gregaria (Orthoptera :Acritidae) is not only confined to Africa, India and Asia Minor, but also affected other areas of the earth infested by other species of locusts. The desert locust is a significant pest in its solitarious phase, in the recession areas, but gregarious phase becomes the major pest when forming swarms stimulated by the rain and improved vegetation (Notle, 1974). The biochemical composition of haemolymph is highly variable among the insect species at different developmental stages (Florkin and Jeuniaux 1974, Thomath and Nair 2011). Since metabolic activities have been reported to be different at different developmental stages in an insect, the fluctuation in the metabolites could indicate rhythmic changes that occur in the biochemistry of insect haemolymph. This could be related to the rhythm of insecticide susceptibility occurring in insects and hence may be of importance in the study of the mode of action of insecticides on the mechanism of resistance of this pest. The total quantity of protein in the blood varies in the course of development. These proteins are usually classified as storage proteins, lipid transport proteins, vitellogenesis, enzymes, proteinase inhibitors, chromo proteins and a range of different proteins that are involved in various immune responses in insects.

Most proteins in an insect body, have been reported to be synthesized in the fat body released into the haemolymph. Locust fat body sustains and assists the formation of the giant locust swarms with perfect flight performance synthesizes, stores and mobilizes energy-rich substrate that are used to overcome periods of starvation to power flight and /or to fuel egg production (Lorenz 2009). Investigation the protein patterns of the fat body of hoppers and adults may help in understanding the biochemical and physiological changes occurred in the solitary form of Sch. gregaria as well as opening new lines in research concerning the locust phase polymorphism.

\subsection{Insect culture:}

\section{Materials and methods}

The stock colony of Sch. gregaria was maintained in the entomology laboratory, Faculty of Science, Cairo University according to Ibrahim (1971). The samples were taken from the haemolymphand fat body of the $5^{\text {th }}$ nymph instar and of male and female adults at three different phases i.e.,newly emerged, before oviposition and after oviposition females, yellow and non-yellow males (mature and non-mature),. The tissue samples were weighed, homogenized and then centrifuged at $6000 \mathrm{r}$. p.m.at $4^{\circ} \mathrm{C}$. The supernatant was diluted 1:1 (vol :vol) with $5 \%$ sucrose solution in preparation of electrophoretic techniques.

\subsection{Electrophoretic technique:}

Electrophoresis was done on $1.5 \mathrm{~mm}$ vertical slab polyacrylamid gel (Sturdier slap gel electrophoresis unite SE 400) at $60 \mathrm{~mA}$.until the tracking dye (bromophenol blue) migrate to the end of the gel. The running gel 
(6\%) was made with $1.5 \mathrm{M}$ tris buffer $(\mathrm{pH} 8.8)$, The stacking gel (4\%) was made with $0.5 \mathrm{M}$ tris buffer (Turunen and Chippendale 1977) diluted to the ratio 1:3 (V/V) with double distilled water. The temperature of the gel was maintained at $7^{\circ} \mathrm{C}$ by refrigerating the gel chamber during run. The supernatant used for direct

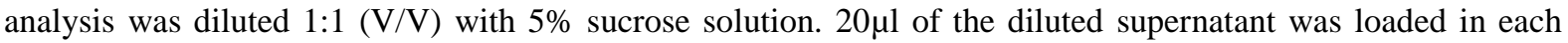
lane. The general protein bands was demonstrated by incubating the gel for one hour in stain solution $(0.125 \%$ Coomassi Brilliant blue COOB, in 50\% ethanol and 10\% acetic acid) and destained the same solvent for maximum constant. Densitometric scanning was made to estimate the relative concentration of the identified bands using Epson GT 8000 scanner at 57-nm wavelength.

\subsection{Relative mobility:}

The total length of the separating gel, the distance travelled by the marker dye in the separating gel and the various distances migrated by the different protein fractions were measured. The relative mobility/relative fraction values of each band was calculated as follows;

Distance travelled by the protein fraction

Relative mobility $(\mathrm{Rm})=$

Distance travelled by the marker dye

According to Abd - Elsamie and Aly (2012), bands that had a relative concentrations of $15 \%$ or over were considered of relatively high concentration (RHC), while that of $5 \%$ or below were considered of relatively low concentrations (RLC). The values between the two extremes (over 5\% and below 15\%) represent moderate concentration(RMC).

\section{Results and Discussion}

Protein patterns of fat body and haemolymph of Sch. gregaria show both qualitative and quantitative changes during the nymph-adult transformation. A total of 37 and 26 bands with different $\mathrm{Rm}$ values were detected in the fat body and the haemolymph respectively.

\subsection{The $5^{\text {th }}$. nymph instar fat body:}

Table(1) and Fig. (1) show that the fat body tissues of the $5^{\text {th }}$ nymphinstar contained 25 bands. These bands were classified into two main groups, bands No.1, 3 5-8, 11-13\&15 have RMC. And bands No. 16-22, 25, $26,28-30,32,33 \& 37$ have RLC.

\subsection{Adult males fat body $\left(\mathrm{N}_{1}, \mathbf{B}_{1} \mathbf{A}_{1}\right)$ :}

Table(1) and Fig. (1) demonstrate that the fat body tissues of $\mathrm{N}_{1}, \mathrm{~B}_{1} \& \mathrm{~A}_{1}$ male instars, amounted to 22 , $19 \& 24$ bands respectively, Similarly to the nymph instar, the newly emerged males (N1) reveal that 10 bands (No. 1,3, 5, 7 , 8, 11, 13, 15,16 \&37) have RMC. 12 bands (No.18-23, 28-31, 34\&36) have RLC. Meanwhile, 7 bands (No.6, 12, 17, 25, 26, $32 \& 33)$ disappeared \&4 bands appeared $(23,31,34 \& 36)$ as compared to nymph instar.

In case of $B_{1}$ individuals, 13 bands $(1-4,6-8,10,11,13,15,17 \& 37$ show RMC whereas,only 6 bands $(22,28-30,32 \& 34)$ show RLC.Five bands appeared (No.2,4\&5) and seven disappeared (No. 5, 16, 18-21\&36) as compared to $\mathrm{N}_{1}$ individuals.

For $\mathrm{A}_{1}$ individuals, 12 bands (No. 1,2,4,5, 7-9, 11-13, 15\&37) show RMC while, 12 bands (No. 17,18, 21-23, 26, 28-30, 32, 34\&36) show RLC. Bands No. 3,6,10, 21\&35)disappeared while bands No. 5, 9, 12, 18 26 appeared.as compared to $N_{1}$ group. Generally, the concentration of the last protein band (37) was duplicated in all male instars as compared to the nymph instar. Also protein band No. 2 was detected only in the fat body tissues of locust males so it is considered as a male fat body specific protein.

\subsection{Adult female fat body $\left(\mathbf{N}_{2}, \mathbf{B}_{2}, \mathbf{A}_{2}\right)$ :}

Table(1) and Fig. (1) show that the fat body tissues of $\mathrm{N}_{2}, \mathrm{~B}_{2} \& \mathrm{~A}_{2}$ female instars, contained 27, $21 \&$ 30 protein bands respectively. Generally, protein concentrations in the fat body of $\mathrm{N}_{2}$ and $\mathrm{B}_{2}$ individuals have the same trend and similar to the males of the same developmental instars. However, three new bands $(5,9 \& 32)$ appeared in $\mathrm{B}_{2}$ and 9bands disappeared $(12,19,20,22,24,26,31,33 \& 34)$ as compared to $\mathrm{N}_{2}$. In case of $\mathrm{A}_{2}$ individuals , the protein concentrations of fat body obviously fluctuated along the $\mathrm{A}_{2}$ lane run. Also a higher number of bands appeared (9- bands) compared to those disappeared (3-bands).

Four protein bands number $24,25,27 \& 35$ were detected only in the female instar therefore,they considered as a female fat body specific protein . In addition, 10 protein bands(No. 1,7,8,11,13,15, 28-30) weredetected in the fat body tissues of all investigated phases $\left(5^{\text {th }}\right.$. nymph instar as well as adult male and female instars) so, they considered as a major fat body protein bands in Sch. gregaria. 


\subsection{The $5^{\text {th }}$. nymph instarhaemolymph:}

Table (2) and Fig. (2) demonstrate that the haemolymph fluid in the $5^{\text {th }}$. nymphinstar contained 20 bands most of them were of RLC except 3 bands No. 3 with RMC, and No.13 \& 22 with RHC. In addition, 2 bands (No. 1\&7) were detected only in the $5^{\text {th }}$. nymph instar.

\subsection{Adult males haemolymph $\left(\mathrm{N}_{1}, \mathbf{B}_{1} \mathrm{~A}_{1}\right)$ :}

Table (2) and fig.(2) show that the native protein bands of the haemolymph of $\mathrm{N}_{1}, \mathrm{~B}_{1} \& \mathrm{~A}_{1}$ male instars, were16, 14\&19 bands respectively. For N1 individuals, bands No. 2,3,5,9,12 \&13 have RMC. Bands No. 15,16,18-21,23 \&24have RLC. However, 2 bands (No.13\&22) have RHC. Five bands (No. 1, 6, 7, 19 \&17) weredisappeared and only one band (No. 19) was appeared as compared to the nymph instar.

For $\mathrm{B}_{1}$ individuals, 8 bands $(2,3,5,8,9,11,12$ \& 22) have RMC. While Five bands (No.15, 20, 23 $25)$ have RLC. Two new bands were appeared $(8 \& 25)$ whereas, 4 bands were disappeared as compared to $\mathrm{N}_{1}$.

For A1 individuals, 13 bands (No.3, 4, 6, 8, 11, 12, 14,1517, 21, 24-26) have RLC. Four bands (No,5, 9, 20 \&23) have RML and only 2 bands (No. 13 \&22) have RHC. Six bands (No. 4, 6, 14, 17, 21 \&26) were appearedwhereas only one band ( No. 2 ) was disappearedas compared to $\mathrm{B}_{1}$

Also 3 bands (No. 18, $19 \& 26$ ) were detected only in the haemolymph of the male instars.

\subsection{Adult females haemolymph $\left(\mathbf{N}_{1}, \mathbf{B}_{1} \mathbf{A}_{1}\right)$ :}

Table (2) and Fig. (2) show that the haemolymph fluid of $\mathrm{N}_{2}, \mathrm{~B}_{2} \& \mathrm{~A}_{2}$ female instars, contained 18, 14 $\& 13$ protein bands respectively.

Protein concentrationsofthehaemolymph of $\mathrm{N}_{2}$ revealed that 12 bands (No. 3, 4, 6, 8, 12, 14, 16, 17, 21 \&23-25) have RLC. Four bands (No.5, 9, 11 \& 20) have RMC and only 2 bands (No. $13 \& 21$ ) have RHC. Seven bands (No. 3, 4, 7, 10, 15, 18 \&25) weredisappeared and only 3 bands (No. 4, 8 \&14) were appeared as compared to the nymph instar.

In case of $\mathrm{B}_{2}$ individuals, 5 bands (No. 2, 6, 14, 20 \& 24) have RLC. Eight bands (No. 3, 5, 8, 9, 11, 12, 15 \&22) have RMC. And only one band (No. 13) has RHC. Six bands (No. 4, 16, 17, 21, 23 \&25) weredisappeared and two bands (No. 2 \&15) were appeared as compared to $\mathrm{N}_{2}$ group.

In case of $A_{2}, 8$ bands (No. 3, 5, 6, 9, 12-15) have RMC. Four bands ( No. 10, 20, 22, \&25) have RLC. And only one band ( No. 11) has RHC. Three bands (No. 2, 8 \&24) weredisappeared and only one band (25) was appeared as compared to $\mathrm{B}_{2}$.

In addition, one protein band (No. 10) was only detected in the female instars, so it is considered as a female haemolymph specific protein .Also, 7 protein bands( No.5, 9, 11-13, 20 \&22) were detected in the haemolymph of all investigated locust phases therefore, they considered as a major haemolymph protein bands in Sch.gregaria.

Odhiambo (1967),suggested that little synthetic machinery takes place in the mature fat body of the male Sch. gregaria at the time the locust attain sexual maturity and is maintained throughout the remaining life. This scanty development of locust fat body in the mature insect may be related to the low feeding activity evident at that time, implying an inadequate circulation of nutrients in the haemolymph. Also he found that there was a rapid increase in total lipids after adult emergence and during early development of adult male reaching a peak at sexual maturity;thereafter there was no increase in lipid content and there was a gradual depletion from the chief energy reserves for locomotion.

Lorenz (2009) and Hill et al.(1968), mentioned that, during the first 10 days of adult life the dry weight of the female desert locust increases by 112percent. This increase is strongly due tothe somatic growth as well as an increase in the content of the haemolymph. During this period of somatic growth the native protein as well as conjugated proteins (glycoprotein, lipoprotein \&glycolipoprotein) accumulate in the fat body and haemolymph. The overian growth only begins towards the end of the somatic growth.

The results obtained in the course of our study are in agreement with these findings since, the concentration percentages as well as the total number of protein bands of the fat body of either males or females reach a peak at the mature stage.

McCormick and Scott (1966) reported that a total of 19 distinct haemolymph protein fractions has been demonstrated during the developmental stages of Locustamigratoria.On the whole the band pattern is fairly constant throughout the locust's development until the locust become sexually mature.

This is also hold true for the haemolymph of mature males (19 bands) however, in case of mature females these figure decreased to 13 band.

This is may be due to the beginning of vitellogenesis and oogenesis.

Our results are in accordance with the findings of Orabi and Ali (1999), who reported that the decline occurred in the protein bands of fat body and haemolymph of the onion fly of the last larval instar and the newly emerged males were due to the histolysis of nymph tissues and histogenesis of newly emerged adult tissues. 
Elliott and Gillott (1979) working on the migratory grasshopper M.sanguinips found that 12 protein bands were detected in the fat body of which 7 had relative mobilities identical to those detected in the ovary .Similarly , 8 of 16 protein bands detected in the haemolymphof the vitellogenic females had electrphoretically identical counterparts in the ovary. The authors suggested that most yolk proteins are synthesized in the fat body and accumulate in the haemolymph .

These findings may explain the presence of female specific proteins in the fat body and haemolymph of Sch. gregaria .

Thomas and Nair (2011)reproted thatThe variation of protein fractions during the different developmental stages of R.ferrugineushaemolymphapparently indicates both the synthesis and breakdown of the specific proteins.Also,

Abd-ElSamie and Aly (2012) mentioned that the esterase isozymes detected in the fat body of the desert locust are involved in the catabolism of juvenile hormone ,pesticides and other compounds, resulting directly in both the synthesisand breakdown of specific proteins.

Table(1):Comparative analysis of relative mobility $(\mathrm{Rm})$ and \% of the protein bands density detected in fat bodies of nymph and adult males and females of Sch. gregaria

\begin{tabular}{|c|c|c|c|c|c|c|c|c|}
\hline \multirow{3}{*}{$\begin{array}{l}\text { and } \\
\text { No. }\end{array}$} & \multirow{3}{*}{$\begin{array}{c}\mathbf{R m} \\
\text { value }\end{array}$} & \multicolumn{7}{|c|}{ \% Protein bands } \\
\hline & & \multirow{2}{*}{ Nymph } & \multicolumn{3}{|c|}{ Male } & \multicolumn{3}{|c|}{ Female } \\
\hline & & & $\mathbf{N}_{1}$ & $\mathbf{B}_{1}$ & $\mathbf{A}_{1}$ & $\mathbf{N}_{2}$ & $\mathbf{B}_{2}$ & $\mathbf{A _ { 2 }}$ \\
\hline 1 & 0.030 & 6 & 7 & 10 & 10 & 6 & 6 & 6 \\
\hline 2 & 0.048 & - & - & 7 & 7 & - & - & - \\
\hline 3 & 0.056 & 5 & 6 & 6 & - & 5 & 5 & 6 \\
\hline 4 & 0.074 & - & - & 7 & 7 & 6 & 6 & - \\
\hline 5 & 0.087 & 5 & 7 & - & 7 & - & 5 & - \\
\hline 6 & 0.11 & 5 & - & 5 & - & 5 & 6 & 4 \\
\hline 7 & 0.14 & 5 & 6 & 8 & 6 & 5 & 5 & 4 \\
\hline 8 & 0.18 & 6 & 7 & 7 & 6 & 6 & 5 & 5 \\
\hline 9 & 0.20 & - & - & - & 5 & - & 6 & 4 \\
\hline 10 & 0.21 & - & - & 5 & - & 5 & 6 & - \\
\hline 11 & 0.23 & 6 & 7 & 5 & 5 & 6 & 8 & 5 \\
\hline 12 & 0.27 & 6 & - & - & 5 & 6 & - & - \\
\hline 13 & 0.30 & 6 & 6 & 5 & 6 & 6 & 7 & 4 \\
\hline 14 & 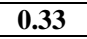 & - & - & - & - & - & - & 3 \\
\hline 15 & 0.35 & 5 & 5 & 5 & 5 & 5 & 6 & 4 \\
\hline 16 & $\begin{array}{l}0.39 \\
\end{array}$ & 4 & 5 & - & - & - & - & 3 \\
\hline 17 & 0.41 & 4 & - & 5 & 4 & 4 & 4 & 3 \\
\hline 18 & 0.44 & 4 & 4 & - & 4 & 3 & 4 & 3 \\
\hline 19 & 0.46 & 3 & 3 & - & - & 2 & - & 3 \\
\hline 20 & 0.48 & 3 & 3 & - & - & 2 & - & - \\
\hline 21 & $\begin{array}{l}0.50 \\
\end{array}$ & 3 & 3 & - & 3 & 2 & 3 & 3 \\
\hline 22 & $\mathbf{0 . 5 3}$ & 3 & 3 & 4 & 3 & 3 & - & 3 \\
\hline 23 & 0.55 & - & 3 & - & 3 & - & - & 2 \\
\hline 24 & 0.59 & - & - & - & - & 3 & - & 2 \\
\hline 25 & 0.62 & 2 & - & - & - & 2 & 2 & 2 \\
\hline 26 & 0.63 & 2 & - & - & 2 & 2 & - & 2 \\
\hline 27 & 0.65 & - & - & - & - & - & - & 3 \\
\hline 28 & 0.66 & 3 & 3 & 3 & 2 & 2 & 3 & 2 \\
\hline 29 & 0.69 & 2 & 3 & 3 & 2 & 2 & 2 & 3 \\
\hline 30 & \begin{tabular}{|l|}
0.72 \\
\end{tabular} & 4 & 4 & 3 & 3 & 2 & 3 & 4 \\
\hline 31 & 0.77 & - & 3 & - & - & 2 & - & 2 \\
\hline 32 & \begin{tabular}{|l|l|} 
\\
\end{tabular} & 2 & - & 3 & 2 & - & 2 & - \\
\hline 33 & 0.84 & 2 & - & - & - & 2 & - & 3 \\
\hline 34 & $\begin{array}{l}0.89 \\
\end{array}$ & - & 3 & 3 & 3 & 1 & - & 2 \\
\hline 35 & 0.91 & - & - & - & - & - & - & 2 \\
\hline 36 & 0.94 & - & 3 & - & 3 & - & - & 3 \\
\hline 37 & 0.97 & 3 & 6 & 6 & 6 & 5 & 6 & 5 \\
\hline Total & & 25 & 22 & 19 & 24 & 27 & 21 & 30 \\
\hline
\end{tabular}

$\mathbf{R m}$ : relative mobility.

$\mathrm{N}_{1}$ : newly emerged males $\mathrm{N}_{2}$ :newly emerged Females .

$B_{1}$ : males before maturation. $B_{2}$ :females before oviposition.

$A_{1}$ : males aftermaturation. $\quad A_{2}$ :females after oviposition. 
Table(2):Comparative analysis of relative mobility $(\mathrm{Rm})$ and $\%$ of the protein bands density detected in the haemolymph of nymph and adult males and females of Sch. gregaria

\begin{tabular}{|c|c|c|c|c|c|c|c|c|}
\hline \multirow{3}{*}{$\begin{array}{l}\text { and } \\
\text { No. }\end{array}$} & \multirow{3}{*}{$\begin{array}{c}\text { Rm } \\
\text { value }\end{array}$} & \multicolumn{7}{|c|}{$\%$ Protein bands } \\
\hline & & \multirow[b]{2}{*}{ nymph } & \multicolumn{3}{|c|}{ Male } & \multicolumn{3}{|c|}{ Female } \\
\hline & & & $\mathbf{N}_{1}$ & $\mathbf{B}_{1}$ & $\mathbf{A}_{1}$ & $\mathbf{N}_{2}$ & $\mathbf{B}_{2}$ & $\mathbf{A}_{2}$ \\
\hline 1 & 0.05 & 3 & - & - & - & - & - & - \\
\hline 2 & 0.06 & 4 & 5 & 3 & - & - & 2 & - \\
\hline 3 & 0.11 & 8 & 6 & 8 & 4 & 1 & 6 & 6 \\
\hline 4 & 0.12 & - & - & - & 1 & 1 & - & - \\
\hline 5 & 0.13 & 4 & 7 & 10 & 6 & 6 & 6 & 6 \\
\hline 6 & 0.15 & 2 & - & - & 1 & 3 & 2 & 7 \\
\hline 7 & 0.16 & 1 & - & - & - & - & - & - \\
\hline 8 & 0.18 & - & - & 11 & 3 & 3 & 5 & - \\
\hline 9 & 0.20 & 3 & 6 & 10 & 7 & 5 & 6 & 8 \\
\hline 10 & 0.23 & 1 & - & - & - & - & - & 3 \\
\hline 11 & 0.26 & 2 & 6 & 13 & 4 & 7 & 11 & 19 \\
\hline 12 & 0.31 & 3 & 5 & 8 & 3 & 3 & 13 & 8 \\
\hline 13 & 0.40 & 30 & 22 & 18 & 21 & 16 & 21 & 14 \\
\hline 14 & 0.46 & - & - & - & 2 & 3 & 3 & 13 \\
\hline 15 & 0.52 & 3 & 4 & 3 & 2 & - & 6 & 9 \\
\hline 16 & 0.54 & 3 & 2 & - & - & 2 & - & - \\
\hline 17 & 0.58 & 2 & - & - & 3 & 3 & - & - \\
\hline 18 & 0.68 & 1 & 3 & - & - & - & - & - \\
\hline 19 & 0.70 & - & 3 & - & - & - & - & - \\
\hline 20 & 0.76 & 4 & 4 & 2 & 6 & 14 & 5 & 1 \\
\hline 21 & 0.85 & 2 & 3 & - & 2 & 3 & - & - \\
\hline 22 & 0.87 & 19 & 16 & 8 & 18 & 18 & 11 & 4 \\
\hline 23 & 0.89 & 3 & 4 & 2 & 9 & 4 & - & - \\
\hline 24 & 0.90 & 2 & 4 & 2 & 4 & 4 & 3 & - \\
\hline 25 & 0.92 & - & - & 2 & 2 & 4 & - & 2 \\
\hline 26 & 0.94 & - & - & - & 2 & - & - & - \\
\hline Total & 0.65 & 20 & 16 & 14 & 19 & 18 & 14 & 13 \\
\hline
\end{tabular}

$\mathrm{Rm}$ : relative mobility.

$\mathrm{N}_{1}$ :newly emerged males. $\mathrm{N}_{2}$ :newly emerged Females .

$\mathrm{B}_{1}$ : males before maturation.

$A_{1}$ :males after maturation.
$B_{2}$ :females before oviposition.

$A_{2}$ :females After oviposition

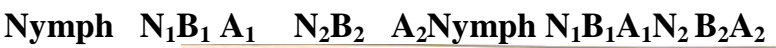

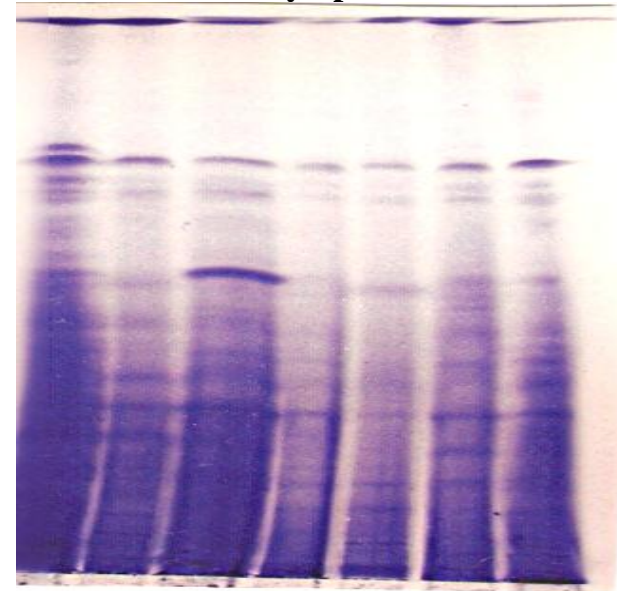

Fig. (1) :Electroph orograph of native protein patterns detected in the fat body tissues of nymph and adult males and females of

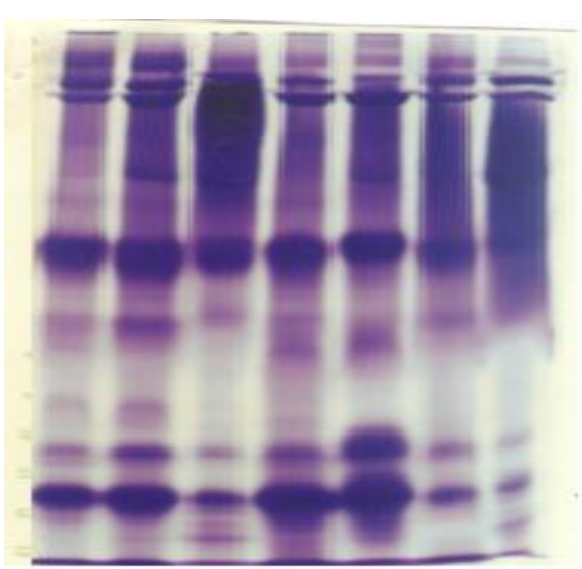

Fig.(2): Electrophorograph of native protein patterns detected in the haemolymphof nymph and adult males and females

Sch. gregaria.of Sch. gregaria

List of abbreviations as in table (1). 


\section{References:}

[1] Notle, D. I.,1974 .The gregarizationof locust.Biol.Rev.,49 : 1- 14

[2] Thomas, A. and Nair, C., 2011. Electrophoratic protein pattern of male and

[3] femalehaemolymph of RhynchophorusferrugineusOlivier. Inter .J. of Farm Sciences., 1: $111-117$.

[4] Lorenz, W. M., 2009. Migration and trans - Atlantic flight locusts . Quaternary international 196: 4 - 12.

[5] Florkin, M. and Jeuniaux, C., 1974. Haemolymphcomposition . In : The Physiology ofInsecta, Rockstein M. (ED), Accademic press, New York, 5 : 255 - 307

[6] Ibrahim, S. I., 1971: Effect of different host plants on biocycle, fecundity and progeny of the locust. SchistocercagregariaForsk (Unpublished Ms. Sc. Thesis Cairo, Univ. ).

[7] Turunen, S. and Chippendale, G. M., 1977.Esterase and lipase activity in themid gut of Diatraeagrandioes lladigestive function and distribution. Insect Biochem., $7: 67-71$.

[8] Abd -Elsamie, E. M. and Aly, G. M., 2012. Esterase isozymes development in the fat body of the solitary form of desert locustSchistocercagregaria(Forskal). Bull. Ent. Soc. Egypt, 89: 187 - 199.

[9] Odhiambo, R. T., 1967. The fine structure and histochemistryof the fat body in the locust, Schistocercagregaria. J. Cell Sci. 235242

[10] Hill, L. Luntz, A. J. and Steele, P. A., 1968, The relationship between somatic growth, overian growth and feeding activity in the adult desert locust. J. of insect physiology 14, 1-20

[11] El-Orabi, M. N. and Ali, G. M. 1999. Effect of sterilizing doses of gamma radiation on protein patterns of Eumerusamoenusloew, (Diptera : Syrphidae).Al-Azhar J. Aric. Res., 30, 215-227.

[12] McCormick, F. W. and Scott. A. 1966, A protein fraction in locust haemolymphassociatedwith the moultingcycle.Cellular and Molecular lifesciences 22, 218-229

[13] Elliott, R. H. and Gillott, C., 1979 An electrophoretic study of proteins of the ovary, fat body and haemolymph in the migratory grasshopper, Melanoplussanguinips. J. insect physiology, 25, 405-410

[14] Thomas, A. and Nair, C., 2011Electrophoretic protein pattern of male and femalehaemolymph of Rhynchophorusferrugineus Olivier. Inter. J. of Farm Sciences 2, 111-117.

[15] Abd-ElSamie, E. M. and Aly, G. M., 2012 Esterase isozymes development in the fat body of the solitary form of desert locust, Schistocerca gregaria (Forskal). Bull.Ent. Soc. Egypt, 89, 187-199. 